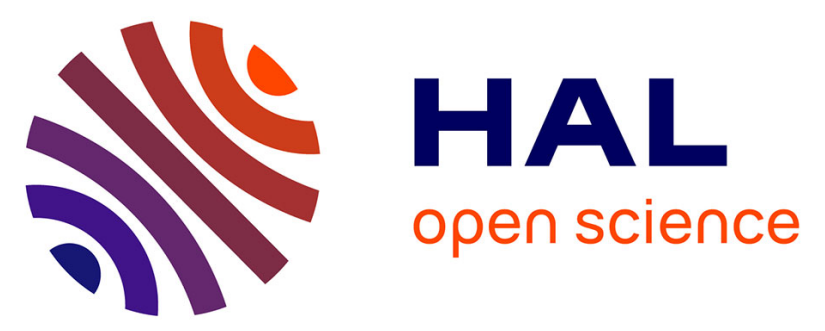

\title{
Effect of storage conditions and subcellular fractionation of fish liver on cytochrome P-450-dependent enzymatic activities used for the monitoring of water pollution
}

\author{
Gilles Monod, Eric Vindimian
}

\section{- To cite this version:}

Gilles Monod, Eric Vindimian. Effect of storage conditions and subcellular fractionation of fish liver on cytochrome P-450-dependent enzymatic activities used for the monitoring of water pollution. Water Research, 1991, 25 (2), pp.173-177. 10.1016/0043-1354(91)90026-M . hal-02715936

\section{HAL Id: hal-02715936 \\ https://hal.inrae.fr/hal-02715936}

Submitted on 1 Jun 2020

HAL is a multi-disciplinary open access archive for the deposit and dissemination of scientific research documents, whether they are published or not. The documents may come from teaching and research institutions in France or abroad, or from public or private research centers.
L'archive ouverte pluridisciplinaire HAL, est destinée au dépôt et à la diffusion de documents scientifiques de niveau recherche, publiés ou non, émanant des établissements d'enseignement et de recherche français ou étrangers, des laboratoires publics ou privés. 


\title{
EFFECT OF STORAGE CONDITIONS AND SUBCELLULAR FRACTIONATION OF FISH LIVER ON CYTOCHROME $P$-450-DEPENDENT ENZYMATIC ACTIVITIES USED FOR THE MONITORING OF WATER POLLUTION
}

\author{
G. MONOD ${ }^{1}$ and E. VINDIMIAN ${ }^{2}$ \\ 'Institut National de la Recherche Agronomique, Laboratoire d'Ecotoxicologie INRA-ENVL, Ecole \\ Nationale Vétérinaire de Lyon, B.P. 8369280 Marcy L'Etoile and ${ }^{2}$ Centre National du Machinisme \\ Agricole du Génie Rural des Eaux et Forêts, Laboratoire d'Ecotoxicologie, 3 Quai Chauveau, 69336 Lyon \\ Cedex 09, France
}

(First received November 1989; accepted in revised form August 1990)

\begin{abstract}
Hepatic cytochrome $P$-450-dependent monooxygenase activities of fish, especially 7-ethylresorufin $O$-deethylase activity (EROD activity) have been proposed as possible indicators of water pollution. Nevertheless there is a need for comparisons between different methods of storage and of subcellular fractionation of the liver with regard to absolute activity and responsiveness of EROD activity to pollution. In this report the livers of nase (Chondrostoma nasus) were collected in PCB-polluted and reference areas of the River Rhône. They were stored in liquid nitrogen either after slicing or after homogenization in phosphate buffer containing $20 \%$ glycerol; subcellular fractionations were performed at the laboratory. Results demonstrate the deleterious effect of freezing slices of liver on EROD activity and point out the protective effect of homogenizing in buffer containing $20 \%$ glycerol (a cryoprotector) prior freezing. Besides, we observed a 3-fold higher EROD activity in the microsomal fraction as compared to postmitochondrial fraction, demonstrating the interest of subcellular fractionation to increase the sensitivity of the assay. Finally, we did not notice any difference between methods of storage and of subcellular preparation with regard to the rate of induction of EROD activity between polluted and reference areas. We conclude that in most cases postmitochondrial fraction originating from liver homogenized in buffer containing $20 \%$ glycerol prior freezing in liquid nitrogen is a useful preparation to measure EROD activity as a pollution indicator.
\end{abstract}

Key words-EROD activity, enzymes, cytochrome $P-450$, PCBs, Chondrostoma nasus

\section{INTRODUCTION}

The chemical pollution of aquatic ecosystems has led to the development of analytical technics able to detect overall pollutants, but during the last decade an increasing interest has been focused on the use of biochemical parameters as indicators of water quality (Haux and Förlin, 1988). It was assumed that a biochemical response should be an early warning signal demonstrating the integration by living organisms of the perturbations of the chemical quality of their environment. In this perspective the study of biotransformation enzymes seems to be promising (Payne et al., 1987).

Biotransformation enzymes are involved in the catabolism of exogenous compounds (pollutants) as well as endogenous substrates (steroids, prostaglandins). Among the several enzymatic systems implicated in biotransformation, there is a considerable interest in cytochrome $P-450$ dependent monooxygenase activities (MO). MO may be modulated (induced or inhibited) by several exogenous molecules. Well known pollutants such as polychlorobiphenyls (PCBs), polyaromatic hydrocarbons (PAHs), poly- chlorodibenzo-dioxins and -furans are potent inducers of particular MO (7-ethylresorufin $O$-deethylase and "aryl hydrocarbon" hydroxylase). Furthermore, induction can lead to toxicological consequences such as carcinogenesis and disturbance of the metabolism of steroids (Buhler and Williams, 1988; Förlin and Haux, 1985). Therefore, MO could be a valuable warning system allowing the detection of hazardous organic micropollutants at presumably toxic levels. Many field studies have shown the inducibility of fish MO by the above pollutants, demonstrating the usefulness of fish $\mathrm{MO}$ as indicators of pollution (Andersson et al., 1988; Monod et al., 1988; Vindimian and Garric, 1989).

Investigations on enzymatic activities of living organisms from the field led to some constrains, especially concerning the storage of the tissues before being back to the laboratory. As cytochrome $P-450$ is a membrane bound enzyme, the conservation procedure may drastically affect its activity; storage into liquid nitrogen is classically used but different methods of preparation of the tissue before freezing are possible. Furthermore, the development of biochemical indicators of pollution must take into 
account the cost of the analysis and the practicability of the procedure: enzymatic activities can be measured on more or less purified sample depending on the level of subcellular fractionation, high level of subcellular fractionation ensures generally a high specific activity but is time-consuming and requires ultracentrifugation.

The first objective of the present study was to assess the influence of storage conditions of the liver by comparing 7-ethylresorufin $O$-deethylase (EROD) activity in liver directly frozen in liquid nitrogen with EROD activity in liver frozen after homogenization in a buffer containing a cryoprotector compound. The second objective was to assess the influence of subcellular fractionation of the liver by comparing EROD activity in microsomal fraction with EROD activity in postmitochondrial fraction. Experiments were conducted with liver of nase (Chondrostoma nasus) caught in the River Rhône in polluted and reference areas which permitted the comparison of the rates of induction exhibited by the different methods.

\section{MATERIAL AND METHODS}

Fish

Nase were collected with net by professional fishermen in November 1988. Fish sampling was performed in two locations of the River Rhône presented in a previous paper (Monod et al., 1988). One of the stations (Miribel) was situated in a chemically polluted area (especially PCBs) and the other one (Pont de Lucey) was considered as a reference. Ten males and ten females were caught in each station.

\section{Liver preparation and subcellular fractionation}

Protocol for liver preparation and subcellular fractionation was summarized in Fig. 1. Nase were sacrificed by a blow on the head then decapitated for bleeding. Each liver was removed and cut in small pieces; one part was wrapped in aluminium foil and directly frozen in liquid nitrogen, the other part was homogenized in $50 \mathrm{mM}$ phosphate buffer, $\mathrm{pH} 7.4$, containing $0.15 \mathrm{M} \mathrm{KCl}$ and $20 \%$ glycerol using a Potter-Elvehjem homogenizer driven by a cordless-drill, then collected in $5 \mathrm{ml}$ cryogenic tubes and frozen in liquid nitrogen.

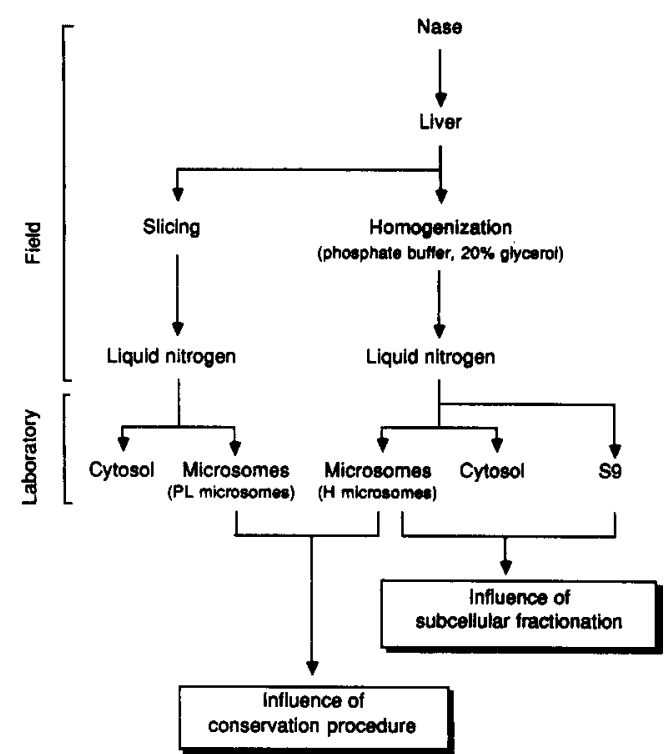

Fig. 1. Protocol for liver preparation and subcellular fractionation.

The day after, at the laboratory, samples were thawed and pieces of liver were homogenized in $50 \mathrm{mM}$ phosphate buffer pH 7.4 containing $0.15 \mathrm{M} \mathrm{KCl}$. All homogenates were centrifuged for $20 \mathrm{~min}\left(10,000 \mathrm{~g}, 4^{\circ} \mathrm{C}\right)$. Supernatant from homogenate (S9) of pieces of liver and one part of supernatant from field-homogenized liver were ultracentrifuged for $60 \mathrm{~min}$ at $105,000 \mathrm{~g}$ at $4^{\circ} \mathrm{C}$, the other part of supernatant from field-homogenized liver ( $\$ 9$ fraction) was conserved at $-80^{\circ} \mathrm{C}$. After ultracentrifugation cytosol was collected and microsomal pellets were resuspended in $50 \mathrm{mM}$ phosphate buffer pH 7.4 containing $1 \mathrm{mM}$ EDTA, $1 \mathrm{mM}$ DTT and $20 \%$ glycerol; cytosolic and microsomal fractions were stored at $-80^{\circ} \mathrm{C}$.

This protocol allowed the comparison of storage conditions using microsomes from field-frozen liver and fieldhomogenized frozen liver, and the comparison of subcellular fractionations using microsomal and $\mathbf{S} 9$ fractions from field-homogenized frozen liver.

\section{Assays}

EROD activity was assayed in a final volume of $1 \mathrm{~m}$ containing $0.1 \mathrm{M}$ phosphate buffer, $\mathrm{pH} 7.4,0.5 \mathrm{mM}$ NADP,

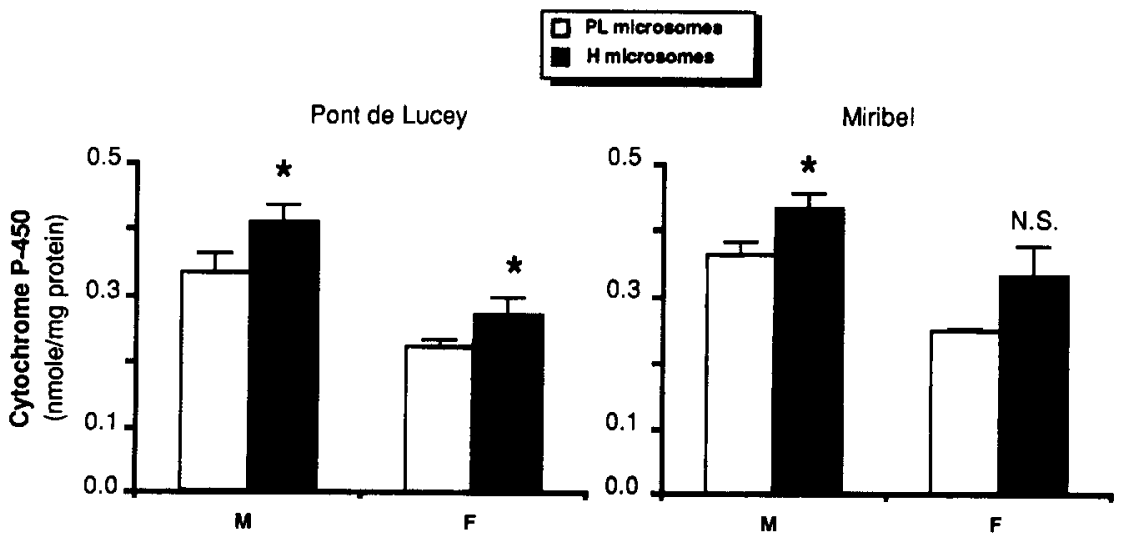

Fig. 2. Cytochrome $P-450$ content in frozen pieces of liver (PL) microsomes and in homogenized liver (H) microsomes of male (M) and female (F) nase caught in reference (Pont de Lucey) and polluted (Miribel) areas. ${ }^{*}$ Significantly different $(P<0.05)$. Each bar represents the mean \pm SEM from 10 fish. N.S. indicates not significantly different. 


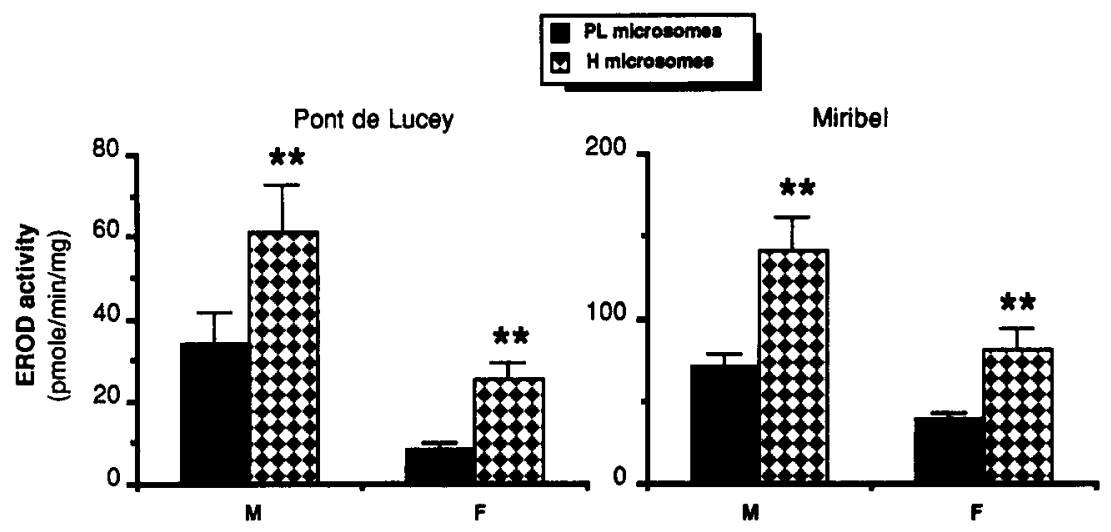

Fig. 3. EROD activity in PL and $\mathrm{H}$ microsomes. See Fig. 2 for further details. * ${ }^{*}$ Significantly different $(P<0.01)$.

$5 \mathrm{mM} \mathrm{G}$ 6-P, 2 unit/ml G 6-PDH, microsomal or S9 protein and $1 \mu \mathrm{M}$ 7-ethylresorufin (added in $10 \mu \mathrm{l} \mathrm{DMSO}$ ). Reaction was stopped by $2 \mathrm{ml}$ acetone and samples were centrifuged in order to remove the protein precipitate. Fluorimetric analysis was performed on the supernatant at excitation wavelength $537 \mathrm{~nm}$ and emission wavelength $583 \mathrm{~nm}$ after standardization by resorufin. The extinction coefficient of resorufin was $73 \mathrm{mM}^{-1}$ (Klotz et al., 1984). Cytochrome $P-450$ content was measured according to Matsubara et al. (1976). Glutathione $S$-transferase (GSH-t) was determined following the method of Habig et al. (1974)

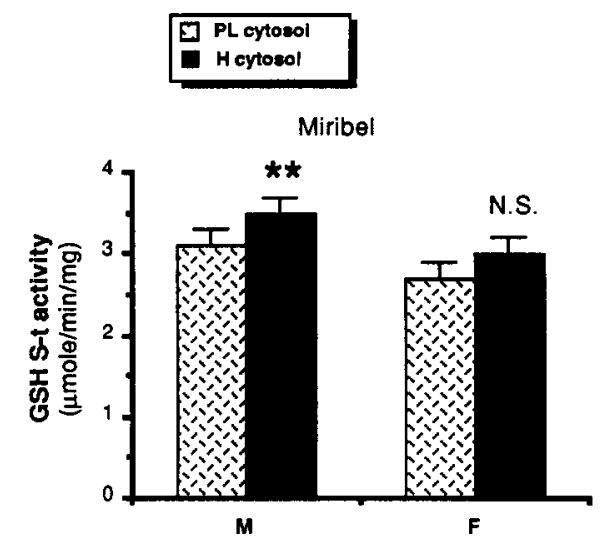

Fig. 4. Glutathione $S$-transferase activity in $\mathrm{PL}$ and $\mathrm{H}$ cytosol. See Fig. 2 for further details. ${ }^{*}$ Significantly different $(P<0.01)$. N.S. indicates not significantly different. with 1-chloro-2,4-dinitrobenzene as a substrate. Protein content was analyzed by the method of Hartree (1972).

\section{Statistics}

As the protocol of liver preparation and subcellular fractionation was performed on each liver, the data obtained from different methods were not independent. Thus, two groups of paired Student's $t$-tests were performed to compare methods of storage and methods of subcellular fractionation.

\section{RESULTS}

As hepatic EROD activity of nase is sex dependent (Masfaraud et al., 1990) the experiments were conducted on each sex.

In Fig. 2 it appears that cytochrome $P-450$ content was slightly but statistically significantly higher in microsomes from field homogenized liver (" $\mathrm{H}$ microsomes") than in microsomes from frozen pieces of liver ("PL microsomes").

Much more pronounced differences were observed considering EROD activity, with the highest activity in "H microsomes" (Fig. 3).

Figure 4 shows that, in males from Miribel but not in females, GSH-t was slightly lower in cytosol from field-frozen pieces of liver than in cytosol from field-homogenized frozen liver. No analyses were performed on fish from Pont de Lucey.

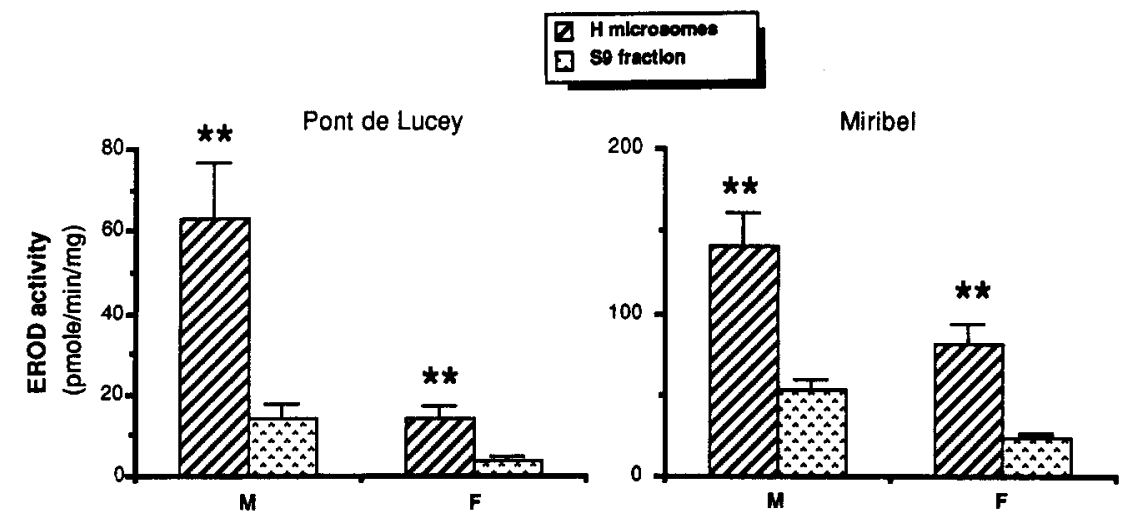

Fig. 5. EROD activity in $\mathbf{H}$ microsomes and $\mathbf{S 9}$ fraction. See Fig. 2 for further details. ${ }^{*}$ Significantly different $(P<0.01)$. 


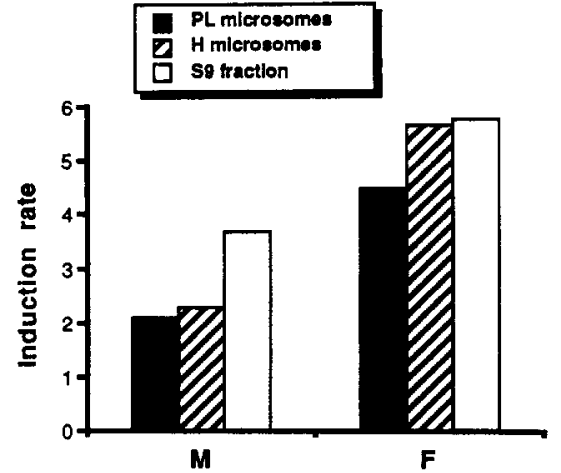

Fig. 6. Induction rate of EROD activity (Miribel activity/ Pont de Lucey activity) measured with PL microsomes, H microsomes and S9 fraction. See Fig. 2 for further details.

Figure 5 clearly shows that an EROD activity 3-4 times higher in $\mathrm{H}$ microsomes than in $\mathrm{S} 9$ fraction was observed in both stations.

Figure 6 points out the fact that the induction rates are of common values whatever the procedure of preparation is.

\section{DISCUSSION}

A significant loss of "biochemical integrity" was observed (with male or female fish from polluted or reference areas) using microsomes from frozen liver instead of microsomes from frozen homogenates containing 20\% glycerol (a cryoprotector). The difference between loss in cytochrome $P-450$ content (about $20 \%$ ) and loss in EROD activity (about $50 \%$ ) might be due to the type of "biochemical integrity" needed. The EROD activity needs the conservation of the catalytic properties of the enzyme whereas the cytochrome $P-450$ content dosage is only dependent on the integrity of the prosthetic heme structure of the cytochrome. As cytochrome $P-450$ is a membrane bound enzyme the alteration of the membrane structure due to freezing without cryoprotector can inhibit the catalytic activity with minor variations in the spectroscopic properties of the heme. The fact that the cytosolic glutathione $S$-transferase (a soluble enzyme) activity is only slightly affected by the direct liver freezing is an other argument for the explanation through a direct membrane alteration. Consequently, the "on field" homogenization of the liver before freezing should be recommended as it prevents the drastic decrease $(50 \%)$ of the EROD activity observed following direct freezing of pieces of liver.

From the comparison of the $\mathbf{S} 9$ and the microsomal enzymatic activities we can conclude that the purification of microsomes increases 3 times the sensitivity of the assay. This increase is not sex dependent and is not significantly affected by the enzymatic induction due to exposure to pollutants.

This study clearly points out the great importance of the conservation and purification procedures used for field studies using cytochrome $P-450$ dependent activities. The EROD activity assay being one of the most widely used whenever fish are concerned, the standardization of the procedure is needed for interlaboratory work. The loss of activity due to liver freezing compared to post homogenization freezing is one of the major points. Furthermore Förlin and Andersson (1985) demonstrated that the freezing of the rainbow trout liver was only efficient for 3 days which is a serious time-limit for the investigation of field areas far from the laboratory. Therefore, so long as homogenization can be quickly and efficiently carried out immediately after the capture of fish using a cordless motor driven homogenizer, this method can be recommended.

The fact that the S9 EROD activity showed the same rate of induction as the microsomal EROD activities (with only a scale factor) is a good argument for the use of $\mathbf{S} 9$ for EROD assay. The purification of microsomes led to the highest activities and should be done when the increase of sensitivity is the major problem.

Acknowledgements-This work was supported in part by a grant from "Ministère de l'Environnement (Service des Recherches et du Traitement de l'Information sur l'Environnement)". We thank P. Buisson and M. Siméon for collecting fish.

\section{REFERENCES}

Andersson T., Förlin L., Härdig J. and Larsson A. (1988) Physiological disturbances in fish living in coastal water polluted with bleached kraft pulp mill effluents. Can.J. Fish. Aquat. Sci. 45, 1525-1536.

Buhler D. R. and Williams D. E. (1988) The role of biotransformation in the toxicity of chemicals. Aquat. Toxic. 11, 19-28.

Förlin L. and Andersson T. (1985) Storage conditions of rainbow trout liver cytochrome $P-450$ and conjugating enzymes. Comp. Biochem. Physiol. 80B, 569-572.

Förlin L. and Haux C. (1985) Increased excretion in the bile of $17 \beta-\left[{ }^{3} \mathrm{H}\right]$ estradiol-derived radioactivity in rainbow trout traited with $\beta$-naphthoflavone. Aquat. Toxic. 6, 197-208.

Habig W. H., Pabst M. J. and Jakoby W. B. (1974) Glutathione $S$-transferase: the first enzymatic step in mercapturic acid formation. J. biol. Chem. 249, $7130-7139$.

Hartree E. F. (1972) Determination of protein: a modifcation of the Lowry method that gives a linear photometric response. Analyt. Biochem. 48, 422-427.

Haux C. and Förlin L. (1988) Biochemical methods for detecting effects of contaminants on fish. Ambio 17, 376-380.

Klotz A. V., Stegeman J. J. and Walsh C. (1984) An alternative 7-ethoxyresorufin $O$-deethylase activity assay: a continuous visible spectrophotometric method for measurement of cytochrome $P-450$ monooxygenase activity. Analyt. Biochem. 140, 138-145.

Masfaraud J. F., Monod G. and Devaux A. (1990) Use of the fish cytochrome $P-450$ dependent 7-ethylresorufin $O$-deethylase activity as a biochemical indicator of water pollution. Study in the liver and the kidney of male nase (Chondrostoma nasus) from the River Rhône. Sci. Total Envir. 97/98, 729-738.

Matsubara T., Koike M., Touchi A., Tochini Y. and Sugeno K. (1976) Quantitative determination of cytochrome $P-450$ in rat liver homogenate. Analyt. Biochem. 75, 596-603. 
Monod G., Devaux A. and Rivière J. L. (1988) Effects of chemical pollution on the activities of hepatic xenobiotic metabolizing enzymes in fish from the River Rhône. Sci. Total Envir. 73, 189-201.

Payne J. F., Fancey L. L., Rahimtula A. D. and Porter E. L. (1987) Review and perspective on the use of mixed- function oxygenase enzymes in biological monitoring. Comp. Biochem. Physiol. 86C, 233-245.

Vindimian E. and Garric J. (1989) Fresh water fish cytochrome $P-450$ dependent enzymatic activities: a chemical pollution indicator. Ecotoxic. envir. Safety 18, 277-285. 